\title{
The Factors Supportive of Democratic Management in Nursery Schools
}

\author{
Vladimíra Hornáčková, Monika Perutková and Ivana Plecháčková \\ Department of Primary and Pre-Primary Education, University of Hradec Králové, Rokitanského 62, Hradec Králové 50003 , \\ Czech Republic
}

\begin{abstract}
The study presents a view of the democratic management in contemporary nursery schools, pointing out the possibility of choosing a management style, which is available to every pedagogical manager. The results of the research survey point out the factors connected with problematic spots in democratic management of nursery schools. They reveal the aspects playing an important role within the school culture and which should receive more attention in order to create the expected positive climate suitable for communication and cooperation with parents. The results presented here draw attention to the weak points in the democratic management and give impulses to introduce changes in favour of an improvement of democratic management of nursery schools.
\end{abstract}

Index Terms - Nursery schools, democratic management, research, pedagogical manager

\section{Introduction}

A very important aspect of nursery schools is the management style chosen by the pedagogical manager. His/her successful or less successful control and management of the nursery school affects the staff, the children and also the parents. Therefore, it is important to ensure a harmonic environment in the nursery school. If the pedagogical manager opts for the democratic nursery school management and gets on well with the pedagogues, children and parents, they are satisfied with the nursery school. Positive democratic management is reflected in the quality of education and improves the image and prestige of the nursery school.

Nursery schools are expected to have democratic management relying on the methods and forms of manager's work characteristic of the modern school management. Nursery schools are characterized by their culture, which is possible to develop and cultivate. The interests, values and needs of the employees and the children play an important role. This puts the pedagogical manager in the position of a coach, guide or mentor, who should understand the personalities of his employees as well as the parents.

What is required in contemporary school management is greater professionalism and awareness of the aspects of the democratic management. Moreover, there is an increased need to react to internal as well as external conditions in a flexible and initiative manner. Problems of the manager - headmaster of a nursery school may be the failure to assert his/her authority to the right extent or a disrespect for the opinion of the group. It depends on the personality and free choice of the pedagogical manager whether he/she makes decisions authoritatively or democratically and what impact they make on the staff but also on the children and their parents. Useful data should be provided by pedagogues' reflection on the management style expressed through selected forms of feedback in a research survey, an analysis of the atmosphere and climate ready for cooperation with parents as well as parents' views of and attitudes to the issue of democratic management in nursery schools.

\section{Theoretical Basis}

A nursery school manager may rely on the democratic management style and operation of the organisation, approaching solution of causes of problems, individual behaviour of the co-workers and the needs of parents and children accordingly. Or, s/he may manage the nursery school in the authoritative or the liberal way.

Let's recall a classical division of management styles autocratic, democratic and liberal:

$>$ Autocratic or authoritative style of management presumes that pedagogical manager commands, prohibits, commands without a discussion, expects to meet his/her proposals and ideas. The manager is decisive, sharp, dogmatic and leads the staff to the possibility of a sanction or reward denial.

$>$ Democratic or participative style of management manifests that the pedagogical manager debates, admits others views and suggestions and consults with them activities and decisions, motivates them in participating of running the nursery school, to cooperate with him/her.

$>$ Liberal style also called as "a free bridle", where the pedagogical manager lets almost everything on the staff with the idea that they would set their goals and means to achieve them, he/she uses a little of his/her power, staff is independent during activities realization. The manager sees his/her role in providing information and with the connection of the outside world, he/she is lenient to deficiencies, tolerates indiscipline, there is a lack of control and motivation at the same time. The leadership is free and the staff has too much of freedom.

By the development of modern accelerated time with very often hectic pace of life that shows a great need to respond to internal and external conditions flexibly, actively and initiatively just in the school management. It evokes the need to have a greater degree of participation on organization management, delegating competences by the headmaster, increased participation of colleagues on decisions making, solving of common and problem situation. To that there is a very helpful proper communication of the pedagogical 
manager with a team of co-workers and providing of good information system. Effective communication in a nursery school is necessary for ensuring of fast and comprehensible information transmission. Each manager should have well developed skills of communication and a communication network.

Manager's properly conducted communication requires:

$>$ A headmaster concentrates on "communique"transmission of information, on the content, formulation, an idea, a link and the feedback

$>$ A headmaster concentrates on non-verbal communication

$>$ A headmaster concentrates on a partner and tries to listen to him/her. Attention should be paid on mistakes in listing, which can be seen in inability to concentrate, focus on a next point, in the lack of interest and in inappropriately selected environment.

Part of properly guided communication is a certain skill to create beliefs with evocations that not everything has been pre-decided, that there are still possibilities where the staff can apply their ideas for new solutions. The creation of a learning organization is presumed by Pohl (2008) as involvement of staff's "heart and brain". Since the beginning everybody has to be aware of what: a) advantage, b) problems (sacrifice) will occur during this process. The people must be convinced that the change is not only necessary but also right and for everyone fair to one another.

Šmelová (2006) states that, the Framework Educational Programme for pre-school education puts a teacher of a kindergarten/nursery school into these roles:

$>$ A role of a protector and a provider of professional care,

A role of a knowledge and an experience provider,

$>$ A role of an adviser and an initiator,

$>$ A role of a diagnostician.

Managers have two possibilities how to influence the behaviour of their staff:

1. To act on rationality of their working attitudes by a vision choice of future successes and thus strategic goals.

2. To act emotionally on their internal needs and motivate them to active implementation of tasks, where they can personally identify with (Pitra, 2007).

Satisfactory aspect for the management support of a bigger nursery school/kindergarten is to create a group of people around the manager (known as expert group), that supports organization's changes and work together with the school management on further school changes leading to a higher quality of education. Evaluation of the current status of executive management should contribute to the implementation of democratic management of nursery schools. A part of self-evaluation is reflection and self-reflection with the use of several forms of a feedback.

The implementation of the democratic management of nursery schools should be supported by evaluation of the present state of management, which is obtainable e.g. through ascertaining the nature of the atmosphere and climate in nursery schools according to fixed criteria (e.g. based on the factors of school culture) or through a reflective insight of parents who put their children in the nursery school.

\section{Research Results - Interpretation and Discussion}

The researchers from the Faculty of Education of the University of Hradec Králové, specifically the members of the Department of Primary and Pre-primary Education prepared specific research projects treating democratic management of nursery schools and analysing school culture in nursery schools, focussing on factors which appear to be dangerous. The present specific research deals with an examination of democratic management in nursery schools from the perspective of parents and builds on a similar project realized in 2014 with the intention to examine more deeply the atmosphere and climate of nursery school management in the Czech Republic.The present research has the following objective:

Research objective:

To analyse the current state of democratic management of nursery schools from the perspective of parents and identify potential reserves according to fixed criteria.

Employed Methods and Techniques: Content analysis, questionnaire.

Research sample: The respondents in the research sample were pedagogical workers in nursery schools (pilotage) and parents of children attending nursery schools (the actual research). Number of respondents: 202 (pilotage: 98)

The employed methods and techniques:

An adaptation of Eger's (2003) questionnaire for the evaluation of factors of school culture (based on questionnaire questions of Kilman, Saxton).

The obtained data was processed using the descriptive methods and correlations.

Verifiable research results:

We present selected results which exhibit the greatest differences between the evaluation of factors which describe the current state and those describing the expected state of nursery school climate and atmosphere. These factors include:

1. The prevalent management style in the nursery school in relation to people

2. Communication of the school with the surroundings and the parents

We offer selected results of the realized research, which lead us to discussion and comparison. We select and present several charts with the most significant items. 


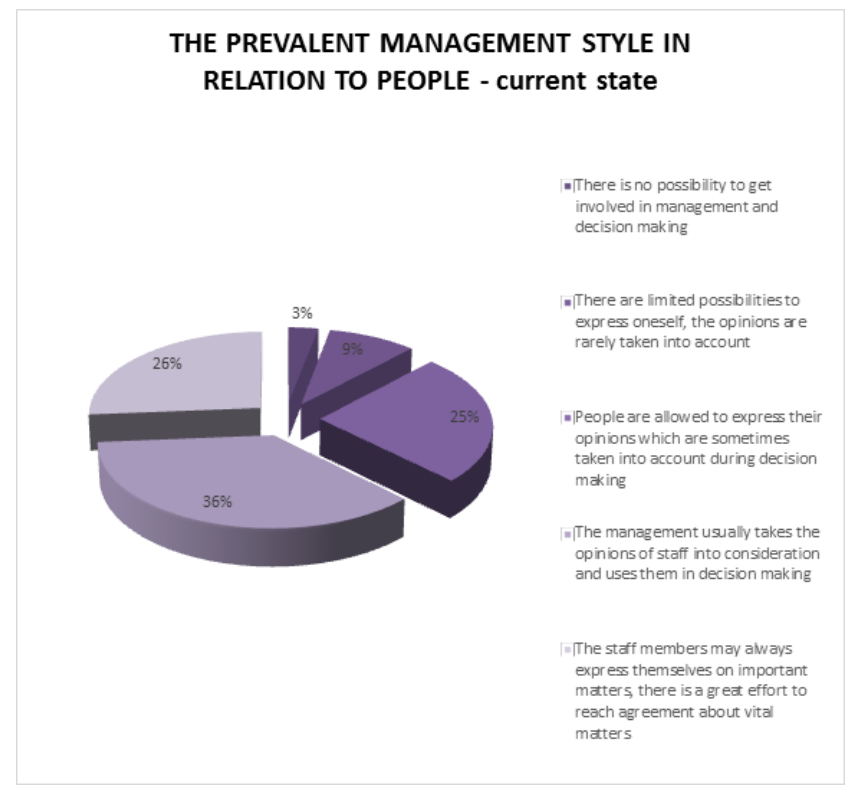

Chart 1: The prevalent management style in relation to people - the current state

Commentary: Chart 1 - shows that only $26 \%$ of respondents can freely express themselves in the matters of management and decision making, $36 \%$ have a limited possibility to express themselves and $25 \%, 9 \%, 3 \%$ have no possibility to get involved in the management of the nursery school. The current prevalent management style in relation to people points out the reserves in the democratic management.

THE PREVALENT MANAGEMENT STYLE IN RELATION TO PEOPLE - the desired, expected state

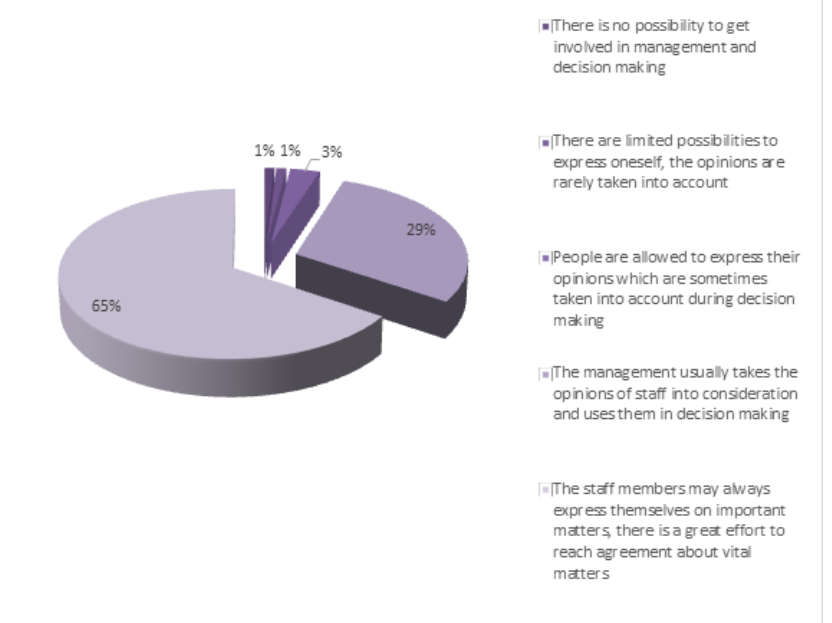

Chart 2: Prevalent management style in relation to people - the desired, expected state

Commentary: Chart 2 - shows the interest of $65 \%$ of respondents to express their opinion of matters and deal with them in cooperation with the management of the nursery school. The visions of $29 \%$ of respondents are limited and so are the possibilities to express one's opinion and apply it. $3 \%$, $1 \%$ and1 \% only can see no possibility to get involved in management and decision making. The chart suggests that respondents have positive visions and ideas about their involvement in democratic management of the nursery school in the future.

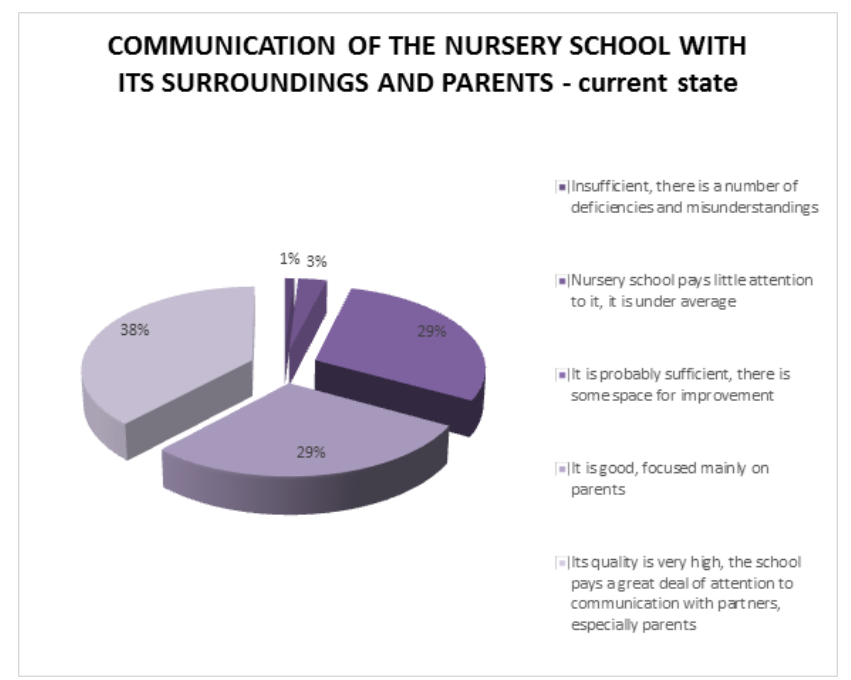

Chart 3: Communication of the nursery school with its surroundings and the parents - current state

Commentary: Chart 3 - represents the current state of the communication of the nursery school with the surroundings and parents. $38 \%$ of respondents evaluate communication with parents as good, $29 \%$ as sufficient and $29 \%$ point out that the nursery school pays little attention to communication. The communication is insufficient for $4 \%$ of respondents. The chart signals that there are considerable reserves in communication with the parents on the part of the nursery school.

\section{COMMUNICATION OF THE NURSERY SCHOOL WITH ITS SURROUNDINGS AND PARENTS - the desired (expected) state}

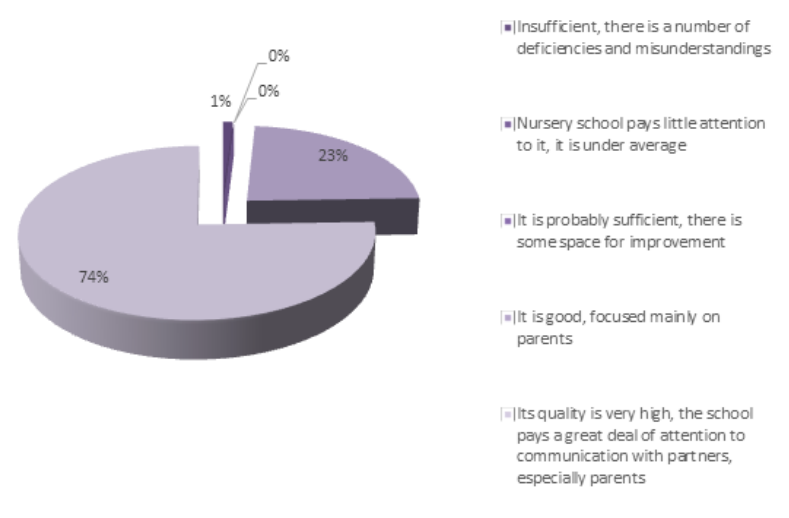

Chart 4: Communication of the nursery school with its surroundings and the parents - the desired, expected 
Commentary Chart 4 - testifies to the positive vision and interest of the respondents. $74 \%$ expect good communication of nursery school with parents. $23 \%$ only see the current state as satisfactory with occasional improvements. $1 \%$ only see communication in future as problematic and insufficient. The positive image expressed by the chart concerning communication with parents is a basis for an improvement on the democratic management of nursery schools.

\section{Conclusions}

The results exposed the factors as well as the problematic spots in the democratic management of nursery schools, showing the weak points of the examined current atmosphere and climate. They point out the deficiencies in the implementation of democratic management of nursery schools, which may affect children, their parents and influence the cooperation of school and family.

This means that in the domain of school management, increased attention should be paid to the given factors having effect on the climate in nursery schools as well as methods and techniques which would support an improvement on the democratic management in nursery schools, mainly in the sphere of leadership.

A felicitous course of future research is to conduct a comparison of all obtained results using identical methodological procedures and provide a complex view of the current management styles in nursery schools from various perspectives.

To conclude, it is possible to state that the results and information obtained through the research project brought stimuli for further scientific investigation and stimuli for innovations of the study of school management in the study programme for university education of preschool pedagogues at the Faculty of Education of the University of Hradec Králové as well as further education of pedagogical managers in the Czech Republic.

\section{References}

[1] Buriánová, Jana, "Řizeni mateřské školy, komplexni přehled všech povinnosti spojených s řizenim MS̆" (Nursery school management: a complex overview of all duties connected with it). Praha: Raabe, 2004.

[2] Eger, Ludvík, "Řizeni školy při zaváděni školniho vzdělávacího programu" (School management during the introduction of the school education programme). Plzeň: Fraus. 2006.

[3] Hornáčková, V. et al, "Analysis of Democratic Leadership Style of Nursery schools/Kindergartens" Procedia - social and behavioral sciences, vol. 171, no. 16, pp. 668-765, January 2015.

[4] KELLEY, P. \& Camilli, F. The Impact of Teacher Education on Outcomes in Center-Based Early Childhood Education Programmes: Meta-analysis, 2007, from http//nieer.org/resources/research/TeacherEd.pdf

[5] Pitra, Z. "Základy managementu”. Praha: Professional Publishing, p. 350 2007.

[6] Pohl, M., "Škola na cestě k učící se organizaci”. Orbis Scholae, 2(3), p. 7-22. 2008.

[7] Šmelová, E.”Mateřská škola a její učitelé v podminkách společenských změn: Teorie a praxe II. “ Olomouc: UP, 160 p., 2006. 